\begin{tabular}{|l|l|l||}
\hline \multicolumn{2}{|c|}{ PublisherInfo } \\
\hline \hline PublisherName & $:$ & BioMed Central \\
\hline \hline PublisherLocation & $:$ & London \\
\hline \hline PublisherImprintName & $:$ & BioMed Central \\
\hline \hline
\end{tabular}

\title{
Cell-free proteomics
}

\begin{tabular}{|l|l|l||}
\hline \multicolumn{2}{|c|}{ ArticleInfo } \\
\hline \hline ArticleID & $:$ & 4627 \\
\hline \hline ArticleDOI & $:$ & $10.1186 /$ gb-spotlight-20021106-01 \\
\hline \hline ArticleCitationID & $:$ & spotlight-20021106-01 \\
\hline \hline ArticleSequenceNumber & $:$ & 293 \\
\hline \hline ArticleCategory & $:$ & Research news \\
\hline ArticleFirstPage & $:$ & 1 \\
\hline \hline ArticleLastPage & $:$ & 2 \\
\hline \hline & & RegistrationDate : 2002-11-6 \\
\hline ArticleHistory & $:$ & OnlineDate \\
\hline \hline ArticleCopyright & $:$ & BioMed Central Ltd2002-11-6 \\
\hline \hline ArticleGrants & $:$ & \\
\hline \hline ArticleContext & $:$ & 130593311 \\
\hline \hline
\end{tabular}




\section{Jonathan B Weitzman}

Email: jonathanweitzman@hotmail.com

Cell-free translation systems offer the speed and accuracy required for automated proteomic analysis. In the Early Edition of the Proceedings of the National Academy of Sciences, Sawasaki et al. describe an optimized system that significantly improves cell-free systems for high throughput analysis. The system, based on the germ extracts, includes optimized 5' and 3' RNA untranslated regions (UTRs) that enhance translation, a high-yield expression vector and convenient PCR-based cloning techniques. The system can be used to generate 50 proteins in large amounts in just two days and the products are stable for up to two weeks. These features, combined with the verified structural and functional integrity of the protein products, suggest that this system is amenable for scale-up and high-throughput analysis.

\section{References}

1. Rate of translation of natural mRNAs in an optimized in vitro system.

2. Proceedings of the National Academy of Sciences, [http://www.pnas.org]

3. A cell-free protein synthesis system for high-throughput proteomics, [http://www.pnas.org/cgi/doi/ 10.1073/pnas.232580399] 